\title{
Idebenone Prevents Oxidative Stress, Cell Death and Senescence of Retinal Pigment Epithelium Cells by Stabilizing BAX/Bcl-2 Ratio
}

\author{
Nicole Arend Christian Wertheimer Peter Laubichler Armin Wolf \\ Anselm Kampik Marcus Kernt \\ Department of Ophthalmology, Ludwig Maximilian University, Munich, Germany
}

\section{Key Words}

Age-related macular degeneration - Oxidative stress .

Apoptosis · Retinal pigment epithelium cells · Cell death

\begin{abstract}
Purpose: Age-related macular degeneration (AMD) is one of the leading causes of blindness. Degeneration of the retinal pigment epithelium (RPE) is pathognomonic for the disease, and oxidative stress plays an important role in the pathogenesis of this disease. This study investigates potential antiapoptotic and cytoprotective effects of idebenone on cultured RPE cells (ARPE-19) under conditions of oxidative stress. Methods: ARPE-19 cells were treated with 1-100 $\mu \mathrm{M}$ idebenone. Cell viability (MTT assay), induction of intracellular reactive oxygen species (ROS) and histone-associated DNA fragments in mono- and oligonucleosomes, expression of proapoptotic BAX and antiapoptotic BCl-2 as well as senescence-associated $\beta$-galactosidase (SA- $\beta$-Gal) activity were investigated under exposure to hydrogen peroxide $\left(\mathrm{H}_{2} \mathrm{O}_{2}\right)$. Results: Idebenone concentrations from 1 to $20 \mu \mathrm{M}$ showed no toxic effects on ARPE-19 cells. When cells were treated with $\mathrm{H}_{2} \mathrm{O}_{2}$, pretreatment with 5, 7.5, 10, and $20 \mu \mathrm{M}$ idebenone led to a significant increase in the viability of ARPE-19 cells. In addition, idebenone pretreatment significantly attenuated the induction of SA- $\beta$-Gal and intracellular ROS as well as the amount of histone-associated DNA frag-
\end{abstract}

ments after treatment with $\mathrm{H}_{2} \mathrm{O}_{2}$. The reduction of proapoptotic $\mathrm{BAX}$ and the elevation of antiapoptotic $\mathrm{BCl}-2$ under idebenone show that this process is rather mediated by inhibiting $\mathrm{H}_{2} \mathrm{O}_{2}$-induced apoptosis, not necrosis. Conclusion: In this study, idebenone increased survival of ARPE-19 cells and reduced cell death, senescence, and oxidative stress by stabilizing the $\mathrm{BAX} / \mathrm{BCl}-2$ ratio.

(c) 2015 S. Karger AG, Basel

\section{Introduction}

Age-related macular degeneration (AMD) is the main reason for severe vision loss in the elderly population worldwide [1-3]. Both dry and wet forms of AMD exist. About $10 \%$ of AMD patients suffer from wet AMD which may result in rapid loss of central vision due to choroidal neovascularization in the central retina [3]. The other $90 \%$ of patients suffer from dry forms, such as geographic atrophy (GA), in which visual acuity usually decreases gradually [3]. Nevertheless, due to the large number of patients affected, the gradual decrease in central vision is a major source of visual impairment in the elderly population. GA is characterized by the atrophy of retinal pigment epithelium (RPE) cells and consecutive photoreceptor degeneration [3]. At present, there is no satisfactory treatment for GA and dry AMD [3].

\section{KARGER 125}

(c) 2015 S. Karger AG, Base

0030-3755/15/2342-0073\$39.50/0

E-Mail karger@karger.com

www.karger.com/oph
Dr. Nicole Arend

Department of Ophthalmology, Ludwig Maximilian University

Mathildenstrasse 8

DE-80336 Munich (Germany)

E-Mail Nicole.arend@med.uni-muenchen.de 
AMD is a multifactorial disease, and the pathogenesis is still not completely understood. However, beside others, increased cumulative light exposure, smoking, hemodynamic abnormalities, and inflammation have been implicated as risk factors [3].

There is substantial evidence that all these risk factors have a common denominator: abnormal increased production of reactive oxygen species (ROS) [4]. In this context, it is of importance that RPE cells are highly susceptible to oxidative stress [5]. One reason for this is that RPE cells contain numerous intracellular photoreactive compounds, including lipofuscin, melanin, and others, absorbing especially in the blue spectral range and thereby promoting the formation of oxygen radicals [6]. In addition, numerous oxygen radical-producing enzymes as well as the high content of fatty acids and the high metabolism rate of the RPE cells contribute to a metabolic imbalance and to an oxidized status [7]. Moreover, regenerating all-trans-retinal from the vision circle and fatty acids for the metabolism of photoreceptor outer segments and the nutritional function of the RPE for the neuroretinal tissue result in an extremely high metabolic activity of RPE cells [8]. As a result, RPE cells have to cope with a highly increased intracellular ROS production [8].

To protect RPE cells from oxidative stress-induced cellular damage, antioxidant supplementation has been proposed as supporting treatment in certain forms of dry AMD [9]. Nevertheless, to date, there is still no satisfactory treatment for GA.

Idebenone is a derivate of coenzyme Q10, but with a ten-fold higher antioxidant capacity. As a component of the respiratory chain it acts as a proton and electron carrier from complex I and II to complex III. The precise mechanisms of its antioxidative and cytoprotective effects are not completely understood, but a number of experimental and clinical studies demonstrated (neuro-)cytoprotective effects in degenerative diseases such as Friedreich's ataxia $[10,11]$ or Leber's hereditary optic neuropathy [12]. In addition, effects on antiapoptotic protein expression have been described [13-15].

The present study evaluates the effect of idebenone on cultured human RPE cells under conditions of oxidative stress.

\section{Methods}

Idebenone was generously provided by Santhera Pharmaceuticals (Liestal, Switzerland). The compound was dissolved in dimethyl sulfoxide (DMSO; Sigma-Aldrich, St. Louis, Mo., USA) and diluted with DMSO and the cell culture medium to the desired concentration, with a final DMSO concentration of $0.1 \%(\mathrm{v} / \mathrm{v})$ for in vitro studies. DMSO was added to cultures at $0.1 \%(\mathrm{v} / \mathrm{v})$ as a solvent control.

Ethics

The methods of securing human tissue were humane, included proper consent and approval, complied with the Declaration of Helsinki, and were approved by the local ethics committee.

\section{ARPE-19 Cell Culture}

ARPE-19 cells, a human RPE cell line, were purchased from ATCC (Manassas, Va., USA) and grown in a 1:1 mixture of Dulbecco's modified Eagle's medium and Ham's F-12 medium (DMEM/Ham's F-12), supplemented with 10\% FCS, 50 IU penicil$\mathrm{lin} / \mathrm{ml}$ and $50 \mu \mathrm{g}$ streptomycin $/ \mathrm{ml}$ (Biochrom) at $37^{\circ} \mathrm{C}$ and $5 \% \mathrm{CO}_{2}$ as described previously [16]. The cell culture medium was changed every 48 h. 100\% confluence was achieved after $72 \mathrm{~h}$ of growing. Only confluent ARPE-19 cells were used for the experiments.

\section{Cell Culture Treatment}

For the tetrazolium dye-reduction assay [3-(4,5-dimethylthiazol-2-yl)-2,5-diphenyltetrazolium bromide (MTT)], ARPE-19 cells were seeded in 12-well tissue culture plates upon confluence for $72 \mathrm{~h}$ and then kept in serum-free conditions (i.e. cell culture medium without FCS, other factors kept constant) for $24 \mathrm{~h}$. Afterwards, they were exposed to various idebenone concentrations (1, $2.5,5,7.5,10,20,50,75,100$, and $150 \mu \mathrm{M})$ for $48 \mathrm{~h}$. To investigate the effects of idebenone on ARPE-19 cells regarding oxidative stress, we used idebenone concentrations of 5 and $10 \mu \mathrm{M}$, which showed the strongest effects in preliminary studies. Regarding ROS, senescence-associated $\beta$-galactosidase (SA- $\beta$-Gal), histoneassociated DNA fragments, and BAX and Bcl-2 concentrations of 5 and $7.5 \mu \mathrm{M}$ were chosen because, here, the antioxidative effect was most intense with a secure distance from the toxic dose. Idebenone has been applied as a pretreatment because as a coenzyme Q10 analogue it acts as an electron carrier in the respiratory chain [17]. Therefore, it is able to immediately eliminate newly built radicals and may be more effective than when applied afterwards. A previous study showed stronger effects with pre- than with posttreatment [18]. Also, we [19] and others [20-22] showed promising results with pretreatment; therefore, we chose this regimen again for the present study.

\section{Exposure to Hydrogen Peroxide}

To test the effects of idebenone under conditions of oxidative stress, ARPE-19 cells were exposed to hydrogen peroxide $\left(\mathrm{H}_{2} \mathrm{O}_{2}\right)$. In preliminary studies of our laboratory, several concentrations of $\mathrm{H}_{2} \mathrm{O}_{2}$ between 400 and 2,000 $\mu \mathrm{M}$ and exposure times were tested, and the concentration of $750 \mu \mathrm{M} \mathrm{H}_{2} \mathrm{O}_{2}$ and a 2-hour treatment were chosen in order to produce an adequate degree of oxidative stress without a too strong cell injury in untreated ARPE-19 cells. A diagrammed presentation of this can be found in figure 1a. To investigate the effect of idebenone on $\mathrm{H}_{2} \mathrm{O}_{2}$-induced cellular damage, cells were seeded upon confluence in 12-well plates as described above and then exposed to the abovementioned different concentrations of idebenone for $48 \mathrm{~h}$, but $750 \mu \mathrm{M} \mathrm{H} \mathrm{H}_{2} \mathrm{O}_{2}$ was added for the last $2 \mathrm{~h}$ (i.e. for $46 \mathrm{~h}$ idebenone only; for $2 \mathrm{~h}$ idebenone plus $\mathrm{H}_{2} \mathrm{O}_{2}$ ). Then, the serum-free medium containing $\mathrm{H}_{2} \mathrm{O}_{2}$ and idebenone was removed by carefully rinsing the cells with serum-free medium three times. After another $24 \mathrm{~h}$ of incubation with serum- 


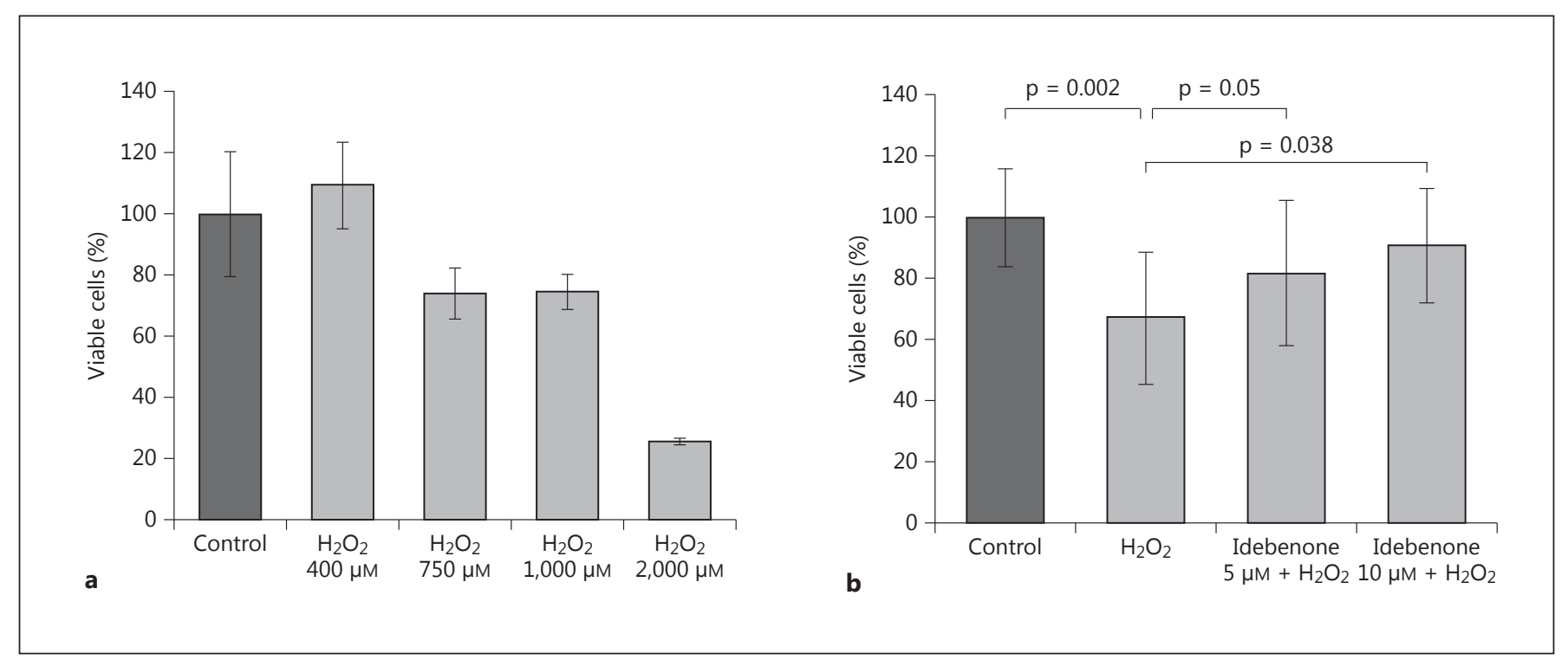

Fig. 1. a Cell viability under a 2-hour treatment with different concentrations of $\mathrm{H}_{2} \mathrm{O}_{2}$. A clear decrease in viability was achieved by exposure to $750 \mu \mathrm{M} \mathrm{H}_{2} \mathrm{O}_{2}$. b Treatment with $\mathrm{H}_{2} \mathrm{O}_{2}$ led to a significant decrease in cell viability. Pretreatment with 5 and $10 \mu \mathrm{M}$ idebenone significantly attenuated the decrease in viability after exposure to $\mathrm{H}_{2} \mathrm{O}_{2}$.

free medium, MTT assay, quantitative detection of histone-associated DNA fragments in mono- and dinucleosomes, and CMH2DCFDA staining and SA- $\beta$-Gal staining were investigated. In addition, RT-PCR analysis and Western blotting were performed.

\section{MTT Assay}

The MTT assay was used to determine metabolic activity of ARPE-19 cells. The MTT assay is a well-established test for an indirect measurement of cell viability by determining the activity of the mitochondrial succinate dehydrogenase and $\mathrm{NAD}(\mathrm{P}) \mathrm{H}$ metabolism. Elevated $\mathrm{NAD}(\mathrm{P}) \mathrm{H}$ as a marker of increased cellular metabolic activity results in an increased reduction of MTT substance. It was performed as described in the literature by Mosmann [23], with some modifications [16, 24]. The medium was removed, cells were washed with PBS, and 1,000 ml/well MTT solution (1.5 $\mathrm{ml}$ MTT stock, $2 \mathrm{mg} / \mathrm{ml}$ in PBS, plus $28.5 \mathrm{ml}$ DMEM) was added. ARPE- 19 cells were incubated at $37^{\circ} \mathrm{C}$ for $1 \mathrm{~h}$. The formazan crystals that formed were dissolved by the addition of DMSO $(700 \mathrm{ml} /$ well). Absorption was measured by a scanning multiwell spectrophotometer (Molecular Probes, Garching, Germany) at $550 \mathrm{~nm}$. Results are expressed as the mean percentage of control extinction. Experiments were performed in triplicate and repeated three times. Untreated ARPE-19 cells of the same passage served as the control. Values of each sample were normalized to a 'blank' containing DMSO only.

\section{Detection of SA- $\beta$-Gal Activity}

The proportion of ARPE- 19 cells positive for SA- $\beta$-Gal activity was determined as described by Dimri et al. [25]. Briefly, treated ARPE-19 cells were washed twice with PBS and fixed with $2 \%$ formaldehyde and $0.2 \%$ glutaraldehyde in PBS ( $\mathrm{pH}$ 6.0) at room temperature for $4 \mathrm{~min}$. The cells were then washed twice with PBS and incubated for $8 \mathrm{~h}$ at $37^{\circ} \mathrm{C}$ with freshly prepared SA- $\beta$-Gal staining solution $[1 \mathrm{mg} / \mathrm{ml}$ 5-bromo-4-chloro-3-indolyl- $\beta$-Dgalactopyranoside, $40 \mathrm{~mm}$ citric acid-sodium phosphate solution (pH 6.0), $5 \mathrm{~mm}$ potassium ferrocyanide, $5 \mathrm{~mm}$ potassium ferricyanide, $150 \mathrm{mM} \mathrm{NaCl}$, and $2 \mathrm{mM} \mathrm{MgCl}_{2}$ diluted in PBS] in darkness. Subsequently, the SA- $\beta$-Gal staining solution was removed, and cells were washed with PBS, examined for the development of blue color, and photographed at low magnification $(\times 200)$ using a light microscope. The amount of SA- $\beta$-Gal-positive cells was counted in 5 high-power fields per experiment at $\times 200$ magnification. The results are expressed as the mean average percentage \pm SD of six experiments using ARPE-19 cultures from four donors.

\section{Detection of Intracellular ROS}

Intracellular ROS production was detected by the method described by Nishikawa et al. [26] with some modifications [27]. RPE cells cultured in the presence of 5 and $7.5 \mu \mathrm{M}$ idebenone were treated with $750 \mu \mathrm{M} \mathrm{H}_{2} \mathrm{O}_{2}$ as described above. Then, the cells were supplemented with 5-(and-6)-chloromethyl-2', $7^{\prime}$-dichlorodihydrofluorescein diacetate acetyl ester (CM-H2DCFDA; Molecular Probes, Eugene, Oreg., USA) dissolved in Krebs-Ringer bicarbonate buffer $(135 \mathrm{~mm} \mathrm{NaCl}, 3.6 \mathrm{mM} \mathrm{KCl}, 10 \mathrm{mM}$ HEPES, $5 \mathrm{~mm}$ $\mathrm{NaHCO}_{3}, 0.5 \mathrm{mM} \mathrm{NaH}_{2} \mathrm{PO}_{4}$, and $0.5 \mathrm{mM} \mathrm{MgCl}_{2}, \mathrm{pH}$ 7.4) to a final concentration of $10 \mu \mathrm{M}$ CM-H2DCFDA for $30 \mathrm{~min}$ and incubated with DMEM/F12 medium for $2 \mathrm{~h}$. Subsequently, CM-H2DCFDA staining solution was removed, cells were washed with PBS and analyzed under an epifluorescence microscope (Aristoplan). The degree of fluorescence was determined as relative fluorescence compared to controls. 


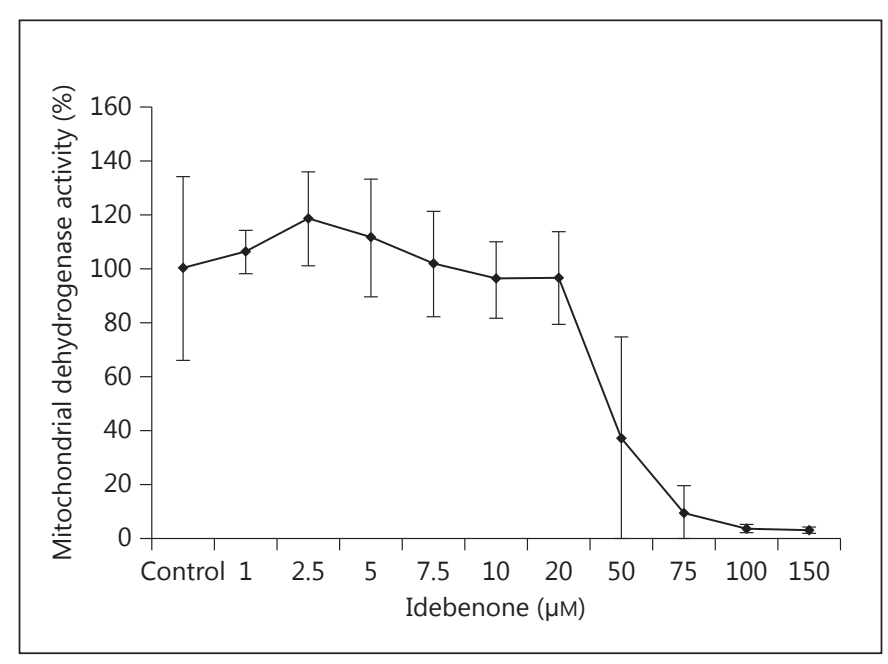

Fig. 2. Toxicity of idebenone. Up to a concentration of $20 \mu \mathrm{M}$, idebenone caused no decrease in the viability of ARPE-19 cells.

Table 1. Primers used for RT-PCR

\begin{tabular}{llccll}
\hline Target & Length Position & $\begin{array}{c}\text { AT, } \\
{ }^{\circ} \mathrm{C}\end{array}$ & $\begin{array}{l}\text { GC, } \\
\%\end{array}$ & Sequence \\
\hline $\mathrm{Bcl}-2$ & 19 & $3465-3483$ & 60 & 58 & agaggtcacgggggctaat \\
& 20 & $3505-3524$ & 60 & 50 & ccaggtaacaaaaccccaca \\
\hline BAX & 18 & $526-543$ & 59 & 61 & caagaccagggtggttgg \\
& 18 & $592-609$ & 59 & 56 & cactcccgccacaaagat \\
\hline
\end{tabular}

$\mathrm{AT}=$ Annealing temperature $\mathrm{GC}=$ guanine-cytosine content .

Detection of Histone-Associated DNA Fragments in Mono- and Oligonucleosomes

Apoptosis is characterized by membrane blebbing, condensation of cytoplasm, and activation of endogenous endonucleases. This leads to internucleosomal cleavage of DNA and the generation of mono- and oligonucleosomes that are tightly complexed with histones. To quantify apoptosis in ARPE-19 cells, detection of histone-associated DNA fragments in mono- and oligonucleosomes was performed by ELISA. ARPE-19 cells were treated with idebenone ( 5 and $7.5 \mu \mathrm{M}$ ) as described above. Cells were then collected from culture plates and subjected to a cell death detection ELISA (Roche Applied Science, Indianapolis, Ind., USA) according to the manufacturer's recommendations [27]. The extinction produced by histone-associated DNA fragments was measured with the ELISA reader. $\mathrm{H}_{2} \mathrm{O}_{2}$-treated cells produce a much higher extinction detected by ELISA than control cells or cells treated with idebenone only. But even without oxidative stress, a certain amount of histone-associated DNA fragments can be measured. To eliminate this 'natural' $\mathrm{H}_{2} \mathrm{O}_{2}$-independent apoptosis, it is recommended by the manufacturer to examine the relative increase in histoneassociated DNA fragments caused by $\mathrm{H}_{2} \mathrm{O}_{2}$ treatment additionally to idebenone or sham treatment. This increase is called 'enrichment factor' and equals the value of extinction of $\mathrm{H}_{2} \mathrm{O}_{2}$-treated cells divided by the value of extinction of untreated cells.

RNA Isolation and Real-Time PCR for BAX and Bcl-2

RNA isolation by using the guanidium thiocyanate-phenolchloroform extraction method and RT-PCR using the LightCycler System (Roche Diagnostics, Mannheim, Germany) was performed as described previously $[24,28]$. Quantitation of Bcl-2 and BAX mRNA was performed with specific primers (table 1). Primers and probes were selected by the ProbeFinder software version 2.04. All primers and probes were designed to cross intron-exon boundaries in order to avoid amplification of genomic DNA. All PCR products were sequenced to ensure product validity. To normalize for differences in the amount of total RNA added to each reaction, $18 \mathrm{~S}$ rRNA was simultaneously processed in the same sample as an internal control. The levels of Bcl-2 and BAX mRNA were determined as the relative ratio, which was calculated by dividing the level of Bcl-2 or BAX mRNA by the level of the 18S rRNA housekeeping gene in the same samples. Ratios are expressed in a decimal format. All experiments were performed at least in triplicate and repeated three times.

\section{Statistical Analysis}

Data was analyzed using SPSS 22 for Windows (SPSS Inc., Chicago, Ill., USA). Quantitative results are presented as means \pm standard deviations. The effect of various idebenone concentrations on cell viability under oxidative stress was statistically tested using the Mann-Whitney test for two independent samples without normal distribution. Statistical comparisons among the different concentrations of idebenone (each repeated three times and measured in triplicate) in testing of ROS, of histone-associated DNA fragments, and of expression of BAX and Bcl-2 and of SA- $\beta-$ Gal were also performed with the Mann-Whitney test. For all statistical tests, $\mathrm{p}<0.05$ was considered significant.

\section{Results}

\section{Cell Viability}

ARPE-19 cells were treated with 1, 2.5, 5, 7.5, 10, 20, $50,75,100$, and $150 \mu \mathrm{M}$ idebenone for $48 \mathrm{~h}$ to investigate potential toxic effects of this substance on the cells. Cells treated with concentrations between 1 and $20 \mu \mathrm{M}$ showed no difference in intracellular mitochondrial dehydrogenase activity, an indirect measure for cellular viability, in the MTT assay. An idebenone concentration of 50, 75, 100 , and $150 \mu \mathrm{M}$ led to a dose-dependent decrease in intracellular mitochondrial dehydrogenase activity (fig. 2).

\section{Effect of Idebenone on $\mathrm{H}_{2} \mathrm{O}_{2}$-Induced Decrease in ARPE-19 Cell Viability}

Results of our preliminary studies with various concentrations of $\mathrm{H}_{2} \mathrm{O}_{2}$ at an exposure time of $2 \mathrm{~h}$ are shown in figure 1a. This time span was found to be the best in previous experiments with different exposure times (data 
not shown). $750 \mu \mathrm{M}$ appeared to be the proper concentration to gain a decrease in cell viability due to oxidative stress without disturbing the cell metabolism too much. This $\mathrm{H}_{2} \mathrm{O}_{2}$ treatment led to a significant decrease in intracellular mitochondrial dehydrogenase activity, an indirect measure for cellular viability, of ARPE-19 cells in the MTT assay [viability of $100 \%$ in control cells vs. $67 \pm 21 \%$ in $\mathrm{H}_{2} \mathrm{O}_{2}$-treated cells $\left.(\mathrm{p}=0.002)\right]$. When pretreated with 5 and $10 \mu \mathrm{M}$ idebenone, cells showed a viability of $81 \pm 23$ and $91 \pm 18 \%$, respectively. So, pretreatment with idebenone led to a significantly higher viability despite the exposure to $\mathrm{H}_{2} \mathrm{O}_{2}(\mathrm{p}=0.05$ for $5 \mu \mathrm{M}$ and $\mathrm{p}=0.038$ for $10 \mu \mathrm{M}$ idebenone; fig. $1 \mathrm{~b}$ ).

\section{Expression of $S A-\beta-G a l$}

SA- $\beta-$ Gal is a well-known marker for cell aging, established especially in research regarding skin aging. In the present study, $\mathrm{H}_{2} \mathrm{O}_{2}$ treatment led to a significant increase in the expression of SA- $\beta-$ Gal $(p=0.01)$. When pretreated with $5 \mu \mathrm{M}$ idebenone, the increase in SA- $\beta-\mathrm{Gal}$ expression mediated by $\mathrm{H}_{2} \mathrm{O}_{2}$ was significantly ameliorated $(\mathrm{p}=0.03$; fig. 3,4$)$.

\section{Expression of Intracellular ROS}

There was no difference between the expression of intracellular ROS in idebenone-treated and control cells. In contrast, $\mathrm{H}_{2} \mathrm{O}_{2}$-treated cells showed a significantly higher expression of intracellular ROS $(\mathrm{p}=0.001)$. Pretreatment with idebenone significantly reduced the expression of intracellular $\mathrm{ROS}$ in $\mathrm{H}_{2} \mathrm{O}_{2}$-treated cells ( $\mathrm{p}=0.01$; fig. 4, 5).

\section{Detection of Histone-Associated DNA Fragments in Mono- and Oligosomes}

Detection of histone-associated DNA fragments was performed by ELISA to investigate a possible antiapoptotic effect of idebenone on ARPE-19 cells. The raw data of extinction read by ELISA are presented in figure $6 \mathrm{a}$. To make the effect of $\mathrm{H}_{2} \mathrm{O}_{2}$ and the protection by idebenone better visible, the data are expressed as enrichment factor as described above, i.e. the multiplication of apoptosis due to $\mathrm{H}_{2} \mathrm{O}_{2}$, and displayed in figure $6 \mathrm{~b}$. Here, treatment with $750 \mu \mathrm{M} \mathrm{H}_{2} \mathrm{O}_{2}$ led to a significant increase in histoneassociated DNA fragments corresponding with a significant increase in apoptosis in control and idebenonetreated cells $(\mathrm{p}=0.0001)$. The factor by which $\mathrm{H}_{2} \mathrm{O}_{2}$ treatment elevated the expression of histone-associated DNA fragments compared to cells without oxidative stress was $12.8 \pm 4.1$ in control cells, $10.4 \pm 3.7$ in cells pretreated with $5 \mu \mathrm{M}$ idebenone, and $6.9 \pm 1.8$ in cells pretreated with $7.5 \mu \mathrm{M}$ idebenone (fig. $6 \mathrm{a}$ ). Figure $6 \mathrm{~b}$ shows this 'enrich-

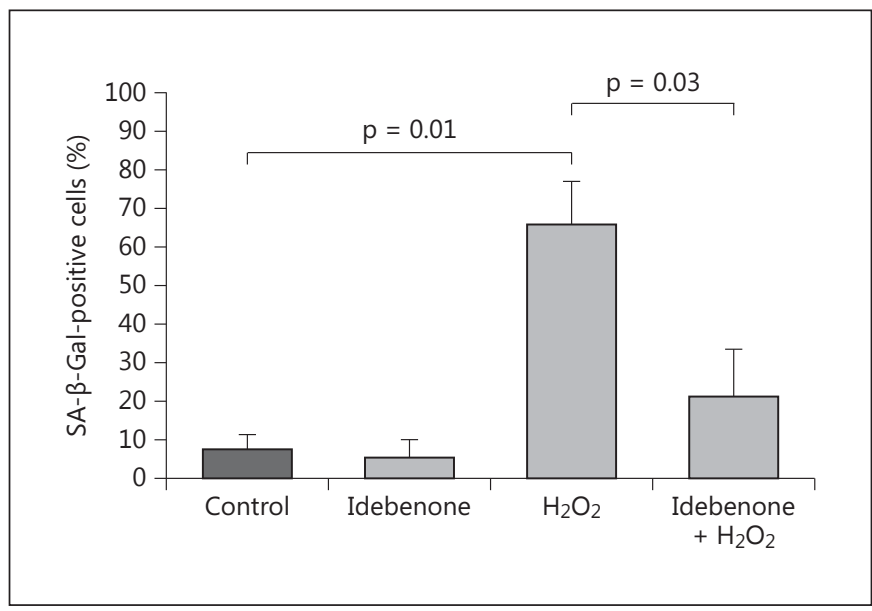

Fig. 3. $\mathrm{H}_{2} \mathrm{O}_{2}$ treatment led to a significant increase in the amount of SA- $\beta$-Gal-positive ARPE- 19 cells. Pretreatment with $5 \mu \mathrm{M}$ idebenone significantly lowered this increase with $\mathrm{H}_{2} \mathrm{O}_{2}$.

ment factor' normalized to the control group (100\%). Pretreatment with $7.5 \mu \mathrm{M}$ idebenone led to a significantly lower enrichment factor $(55.9 \pm 16.8 \%$; $\mathrm{p}=0.001) \mathrm{com}$ pared to control cells; $5 \mu \mathrm{M}$ idebenone showed this by trend $(79.2 \pm 21.9 \% ; \mathrm{p}=0.058)$, and the difference between idebenone 5 and $7.5 \mu \mathrm{M}$ was significant $(\mathrm{p}=0.001)$.

\section{mRNA Expression of $B A X$ and $B c l-2$}

In order to confirm that the detected increase in histone-associated DNA fragments is caused by apoptosis, not by necrosis, we quantified the mRNA expression of the proapoptotic protein BAX and the antiapoptotic protein Bcl-2. As both need to be in a steady balance to allow normal cell survival, we also calculated the $\mathrm{BAX} / \mathrm{Bcl}-2$ ratio. After normalization to the control group, expression of $\mathrm{BAX}$ was $100 \%$ in control cells, $136 \pm 28 \%$ in $\mathrm{H}_{2} \mathrm{O}_{2^{-}}$ treated cells, $115 \pm 9 \%$ in cells treated with $\mathrm{H}_{2} \mathrm{O}_{2}$ and $5 \mu \mathrm{M}$ idebenone, and $103 \pm 35 \%$ in cells treated with $\mathrm{H}_{2} \mathrm{O}_{2}$ and $7.5 \mu \mathrm{M}$ idebenone. Expression of Bcl-2 was $100 \%$ in control cells, $70 \pm 20 \%$ in $\mathrm{H}_{2} \mathrm{O}_{2}$-treated cells, $83 \pm 49 \%$ in cells treated with $\mathrm{H}_{2} \mathrm{O}_{2}$ and $5 \mu \mathrm{M}$ idebenone, and $115 \pm 57 \%$ in cells treated with $\mathrm{H}_{2} \mathrm{O}_{2}$ and $7.5 \mu \mathrm{M}$ idebenone. Therefore, the $\mathrm{BAX} / \mathrm{Bcl}-2$ ratio was $100,211 \pm 86,170 \pm 83$, and 112 $\pm 67 \%$, respectively. So, exposure of ARPE-19 cells to $\mathrm{H}_{2} \mathrm{O}_{2}$ led to a significant increase in the proapoptotic $\operatorname{BAX}(\mathrm{p}=0.037)$, to a significant decrease in the antiapoptotic Bcl-2 ( $\mathrm{p}=0.034)$, and to a subsequent significant increase in the $\mathrm{BAX} / \mathrm{Bcl}-2$ ratio $(\mathrm{p}=0.037$; fig. 7$)$. Pretreatment with idebenone led to a dose-dependent decrease in proapoptotic BAX and an increase in antiapop- 


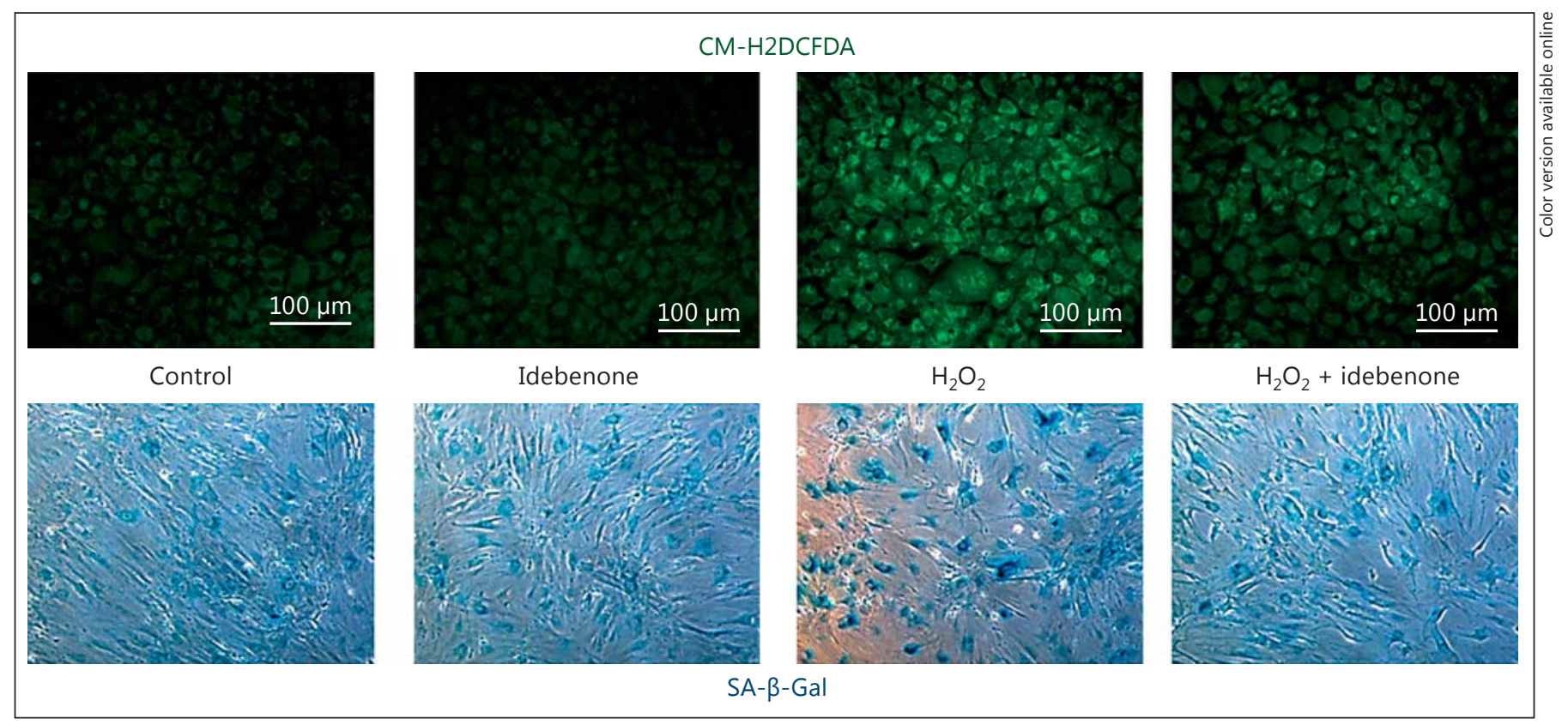

Fig. 4. Treatment with $\mathrm{H}_{2} \mathrm{O}_{2}$ increased the expression of intracellular ROS (upper row) and SA- $\beta$-Gal (lower row) in ARPE-19 cells. Pretreatment with $5 \mu \mathrm{M}$ idebenone markedly inhibited this increase with $\mathrm{H}_{2} \mathrm{O}_{2}$.

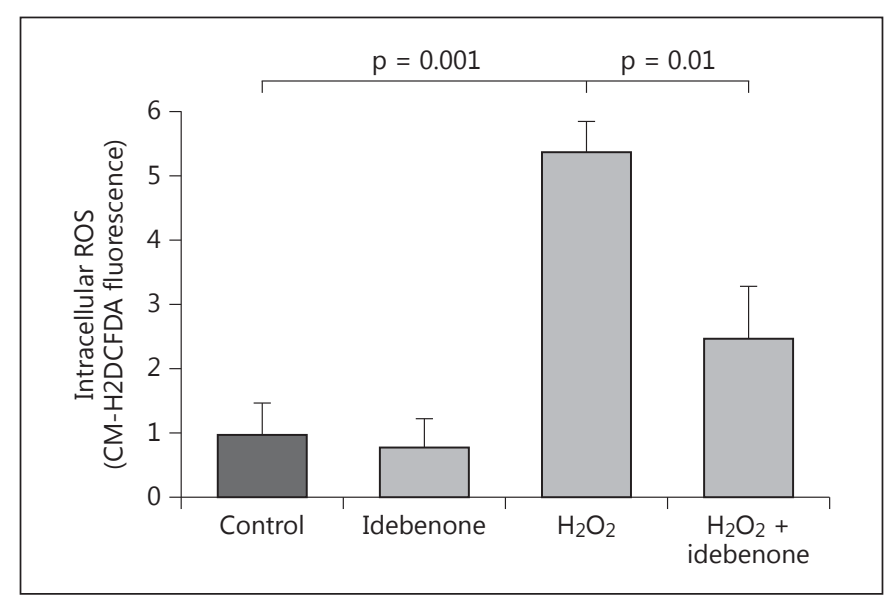

Fig. 5. There was no difference in the expression of ROS between idebenone-treated cells and controls. $\mathrm{H}_{2} \mathrm{O}_{2}$ treatment led to a significant increase in fluorescence due to intracellular ROS. Pretreatment with $5 \mu \mathrm{M}$ idebenone significantly attenuated this increase in ROS fluorescence.

totic $\mathrm{Bcl}-2$ under oxidative stress, which resulted in a normalization of the elevated $\mathrm{BAX} / \mathrm{Bcl}-2$ ratio. These results were clearly recognizable as shown in figure 7 , but due to the relatively high standard deviation they were not statistically significant at a p level of 0.05 .

\section{Discussion}

To date, not all mechanisms involved in the development and progression of AMD to retinal pigment epithelial atrophy and consecutive photoreceptor degeneration are completely understood. Nonetheless, oxidative stress seems to be a central mechanism through which known risk factors, e.g. advanced age, smoking, or UV light, have an impact on retinal cell death [4]. In addition, there seems to be no doubt that induction of oxidative stress and oxygen radicals promote cellular apoptosis.

Apoptosis is a cell-autonomous mechanism that is genetically controlled by the dying cell, resulting in the activation of tumor suppressor proteins [29] and apoptosisinitiating caspases [30]. A number of studies found that apoptosis plays an important role in retinal cell death, both in physiological and pathological conditions, and particularly in AMD [5, 31-33]. Dunaief et al. [34], for example, demonstrated in vivo the involvement of apoptosis in RPE cell death at the margins of GA in dry AMD eyes, and Hinton et al. [31] showed an involvement of apoptosis in choroidal neovascularization membranes of patients suffering from neovascular AMD. Numerous in vitro investigations revealed that retinal cell apoptosis is mediated by oxidative stress $[5,35,36]$. In addition, apoptosis due to oxidative stress is characterized not only by 


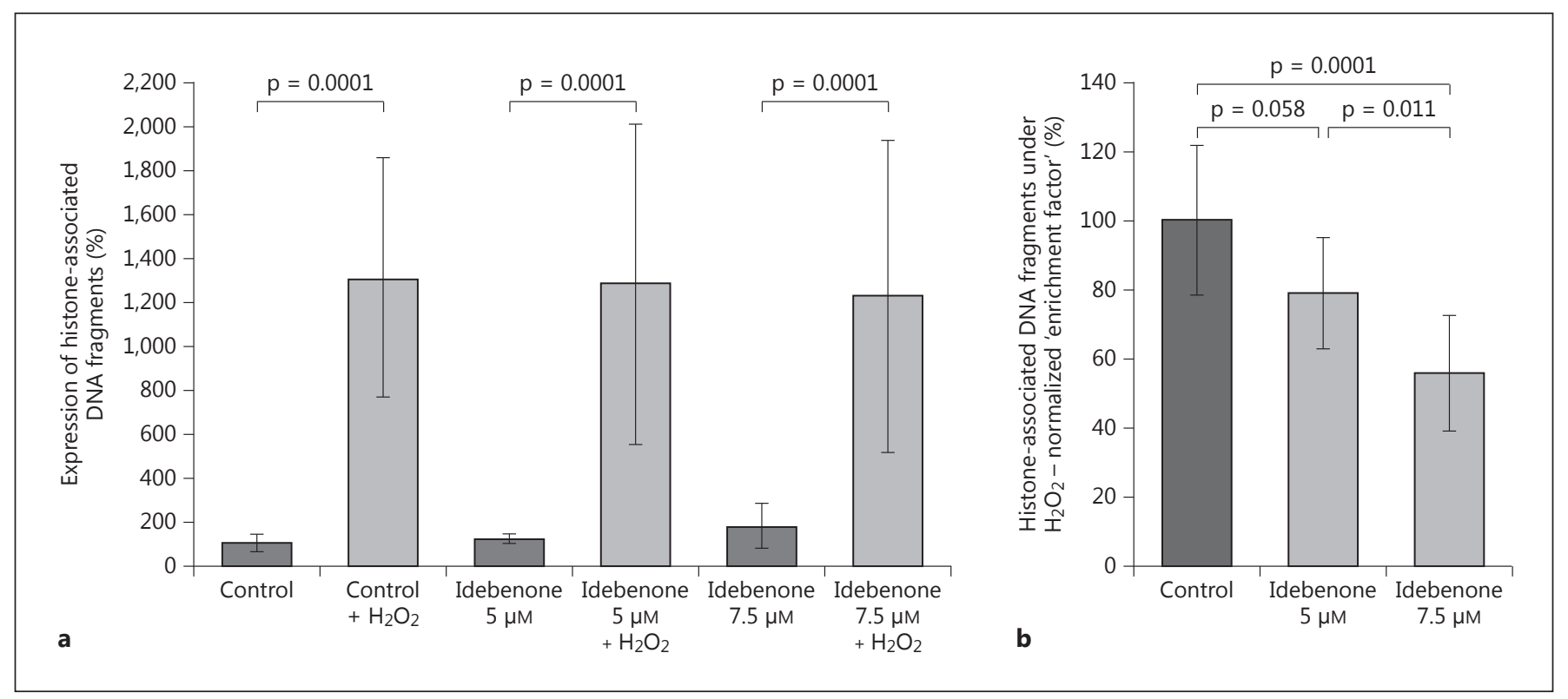

Fig. 6. a Gross expression of histone-associated DNA fragments in the different treatment groups. $\mathrm{H}_{2} \mathrm{O}_{2}$ treatment significantly increased this expression. $\mathbf{b}$ Elevated expression of histone-associated DNA fragments in control ARPE-19 cells due to $\mathrm{H}_{2} \mathrm{O}_{2}$ treatment, normalized to control. Pretreatment with 5 and $7.5 \mu \mathrm{M}$ idebenone significantly attenuated apoptosis following $\mathrm{H}_{2} \mathrm{O}_{2}$ treatment resulting in a significantly lower expression of histone-associated DNA fragments.

elevated caspase levels, but also by an increase in the proapoptotic protein BAX and a decrease in the antiapoptotic protein Bcl-2 [27, 37-39]. BAX activates caspases by upregulating the tumor suppressor gene $\mathrm{p} 53[40,41]$, and Bcl-2 inhibits caspases by stabilizing the permeability of the mitochondrial membrane [41]. An imbalanced relation of these proteins puts the cells in a proapoptotic state. Former studies showed this for several cell types [37-39] and especially for retinal cells $[20,42]$.

In this study, we were able to show that exposure of ARPE-19 cells to oxidative stress leads to a decrease in the viability of RPE cells and an increased formation of intracellular ROS. This decrease in viability is caused by RPE cell apoptosis, not necrosis, as shown by the significantly elevated expression of histone-associated DNA fragments and the elevated $\mathrm{BAX} / \mathrm{Bcl}-2$ ratio. In addition, the strongly elevated expression of SA- $\beta-\mathrm{Gal}$ indicates promotion of cellular aging under $\mathrm{H}_{2} \mathrm{O}_{2}$. SA- $\beta-\mathrm{Gal}$ is a well-established marker for cellular aging, mainly known from dermatological studies. It represents the enzymatic level of cell senescence with expansion of the lysosomal compartment [43]. It is only expressed by senescent, not presenescent cells, e.g. fibroblasts and keratinocytes [25, 44]. Also, in the eye, SA- $\beta-$ Gal is elevated in senescent

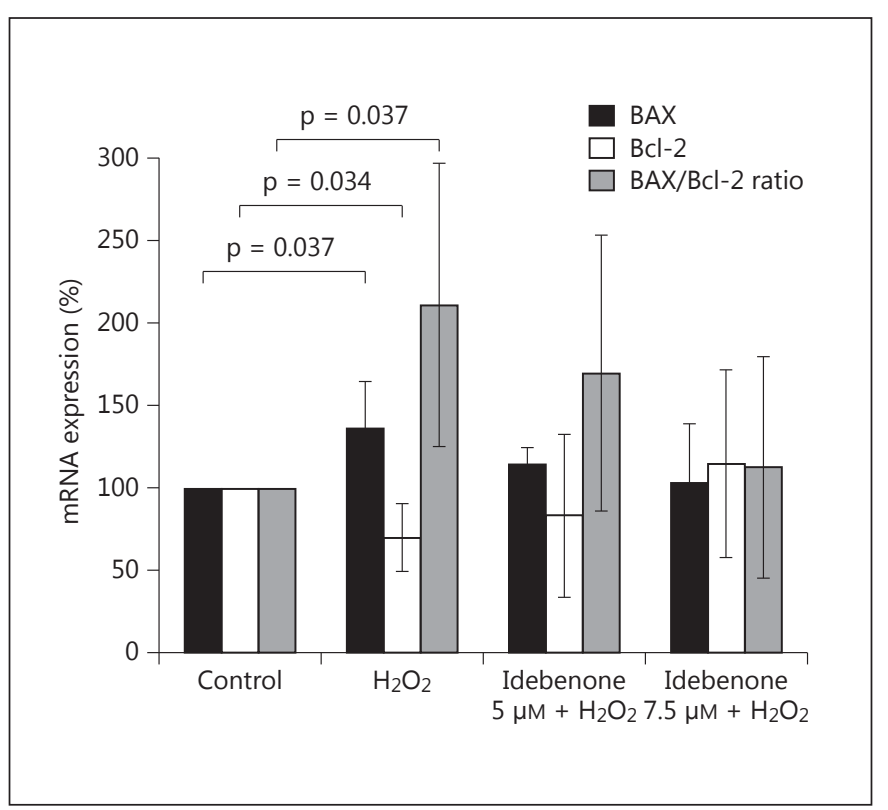

Fig. 7. mRNA expression of $\mathrm{BAX}$ and $\mathrm{Bcl}-2$ and the $\mathrm{BAX} / \mathrm{Bcl}-2$ ratio in control cells, $\mathrm{H}_{2} \mathrm{O}_{2}$-treated cells, and idebenone- plus $\mathrm{H}_{2} \mathrm{O}_{2}$-treated cells. $\mathrm{H}_{2} \mathrm{O}_{2}$ significantly elevated the BAX/Bcl-2 ratio, which indicates a disturbed balance and a shift into a proapoptotic state. Idebenone pretreatment prior to $\mathrm{H}_{2} \mathrm{O}_{2}$ treatment attenuated this shift. 
cells [19]. So, the results of this study underline the pivotal role of oxidative stress in aging and apoptosis of RPE cells.

While antioxidants are used to potentially prevent the progression of early and intermediate stages of AMD, still, in the majority of patients, the disease progresses over time and no effective treatment exists to stop apoptotic RPE cell death in advanced nonneovascular AMD [45].

Idebenone is a synthetic analogue of ubiquinone with a ten-fold higher potency. It acts as an electron carrier between the complexes of the respiratory chain and, therefore, influences the electric balance within the mitochondrion [15]. Furthermore, it inhibits lipid peroxidation and stabilizes the mitochondrial membrane via this pathway $[17,46]$. This underlines potential antiapoptotic as well as antioxidant effects of idebenone.

In the present study, ARPE-19 cells pretreated with idebenone showed significantly less formation of intracellular ROS after exposure to $\mathrm{H}_{2} \mathrm{O}_{2}$. This indicates the potential of idebenone to ameliorate the cytotoxic effects of oxidative stress on RPE cells as a potential approach to prevent progression of dry AMD. In addition, cells pretreated with idebenone showed significantly better viability under oxidative stress.

An important finding of our study is that idebenone inhibited an increase in SA- $\beta$-Gal in RPE cells under the conditions of oxidative stress. As mentioned above, the SA- $\beta$-Gal enzyme is strongly correlated with ageing processes. This may indicate an antiaging effect of idebenone.

Previous studies demonstrated antiapoptotic effects of idebenone on several cell types [19, 47-49]. To date, the use of idebenone and research regarding idebenone are focused on its protective effects on neuronal cells and tissues. The first studies evaluated effects on the murine brain under hypoxia [50]; later on, it became a clinical treatment for patients with Friedreich's ataxia [10] and Leber's hereditary optic neuropathy [12]. Our recently published study showed its antiapoptotic, antioxidative, and antiaging effects on primary optic nerve head astrocytes in terms of glaucoma treatment [19]. Rather few studies evaluated other tissues, such as kidney, and also showed promising antioxidative effects [51]. AMD is an important oxidative stress-related eye disease whose treatment options are still not exhausted [3]. The epithelial tissue of the retina plays an important role in the pathogenesis of this disease [3]. Therefore, one aim of our study was to evaluate the effects of idebenone on RPE cell apoptosis after exposure to oxidative stress. $\mathrm{H}_{2} \mathrm{O}_{2}$ treat- ment led to a significant increase in apoptosis, which could be demonstrated in terms of significantly more histone-associated DNA fragments and an elevated BAX/ Bcl-2 ratio due to an increase in the proapoptotic BAX and a decrease in the antiapoptotic Bcl-2. Idebenone significantly reduced histone-associated DNA fragments in a dose-dependent manner and led to a normalization of the $\mathrm{BAX} / \mathrm{Bcl}-2$ ratio. These findings indicate a protective impact of idebenone on RPE cell apoptosis after exposure to oxidative stress. Thus, the present study contributes to the evaluation of idebenone as a protective agent in nonneuronal tissue.

We are aware that we did not provide confirming data from an animal model. However, many in vivo studies showed much potential of idebenone against oxidative stress in the eye $[12,52,53]$ and other organs $[13,21,54]$. Antioxidants already are a major pillar of AMD therapy, but they are still not fully satisfactory. Therefore, idebenone as an agent which can prevent optic nerve head astrocytes and retinal ganglion cells from apoptosis and which can successfully treat Leber's hereditary optic neuropathy is worth to be further investigated regarding AMD therapy. The present study makes a small contribution to this objective.

\section{Conclusion}

Our experiments show substantial cytoprotective effects of idebenone mediated by inhibition of oxidative stress and protection of RPE cells from cellular aging processes. This leads to a significant inhibition of oxidative stress-related apoptosis of RPE cells. Therefore, our in vitro results imply that idebenone may have the required properties of a potential future therapeutic agent of AMD in vivo.

\section{Acknowledgement}

The authors thank Katja Obholzer for perfect technical assistance.

\section{Disclosure Statement}

The authors have no financial or competing interests concerning the present study.
Arend/Wertheimer/Laubichler/Wolf/ Kampik/Kernt 


\section{References}

$>1$ Klein R, Peto T, Bird A, Vannewkirk MR: The epidemiology of age-related macular degeneration. Am J Ophthalmol 2004;137:486-495.

2 World Health Organization: Visual Impairment and Blindness. WHO, 2011.

$\checkmark 3$ Coleman HR, Chan CC, Ferris FL 3rd, Chew EY: Age-related macular degeneration. Lancet 2008;372:1835-1845.

4 Zarbin MA: Current concepts in the pathogenesis of age-related macular degeneration. Arch Ophthalmol 2004;122:598-614.

5 Wang Y, Shen D, Wang VM, Yu CR, Wang RX, Tuo J, Chan CC: Enhanced apoptosis in retinal pigment epithelium under inflammatory stimuli and oxidative stress. Apoptosis 2012;17:1144-1155.

-6 Nilsson SE, Sundelin SP, Wihlmark U, Brunk UT: Aging of cultured retinal pigment epithelial cells: oxidative reactions, lipofuscin formation and blue light damage. Doc Ophthalmol 2003; 106:13-16

7 Bazan NG, Calandria JM, Serhan CN: Rescue and repair during photoreceptor cell renewal mediated by docosahexaenoic acid-derived neuroprotectin D1. J Lipid Res 2010;51:20182031.

>8 Cai J, Nelson KC, Wu M, Sternberg P Jr, Jones DP: Oxidative damage and protection of the RPE. Prog Retin Eye Res 2000;19:205-221.

$>9$ Kansagara D, Gleitsmann K, Gillingham M, Freeman M, Quinones A: Nutritional Supplements for Age-Related Macular Degeneration: A Systematic Review. Washington, Department of Veterans Affairs, 2012.

10 Lynch DR, Perlman SL, Meier T: A phase 3, double-blind, placebo-controlled trial of idebenone in Friedreich ataxia. Arch Neurol 2010;67:941-947.

-11 Mancuso M, Orsucci D, Choub A, Siciliano G: Current and emerging treatment options in the management of Friedreich ataxia. Neuropsychiatr Dis Treat 2010;6:491-499.

12 Klopstock T, Yu-Wai-Man P, Dimitriadis K, Rouleau J, Heck S, Bailie M, Atawan A, Chattopadhyay S, Schubert M, Garip A, Kernt M, Petraki D, Rummey C, Leinonen M, Metz G, Griffiths PG, Meier T, Chinnery PF: A randomized placebo-controlled trial of idebenone in Leber's hereditary optic neuropathy. Brain 2011;134(Pt 9):2677-2686.

13 Gerhardt E, Graber S, Szego EM, Moisoi N, Martins LM, Outeiro TF, Kermer P: Idebenone and resveratrol extend lifespan and improve motor function of HtrA2 knockout mice. PLoS One 2011;6:e28855.

-14 Palumbo M, Russo A, Cardile V, Renis M, Paolino D, Puglisi G, Fresta M: Improved antioxidant effect of idebenone-loaded polyethyl-2-cyanoacrylate nanocapsules tested on human fibroblasts. Pharm Res 2002;19:7178.

15 Becker C, Bray-French K, Drewe J: Pharmacokinetic evaluation of idebenone. Expert Opin Drug Metab Toxicol 2010;6:1437-1444.
16 Kernt M, Neubauer AS, Ulbig MW, Kampik A, Welge-Lussen U: In vitro safety of intravitreal moxifloxacin for endophthalmitis treatment. J Cataract Refract Surg 2008;34:480488.

17 Haefeli RH, Erb M, Gemperli AC, Robay D, Courdier Fruh I, Anklin C, Dallmann R Gueven N: NQO1-dependent redox cycling of idebenone: effects on cellular redox potential and energy levels. PLoS One 2011; 6:e17963.

18 Rego AC, Santos MS, Oliveira CR: Influence of the antioxidants vitamin $\mathrm{E}$ and idebenone on retinal cell injury mediated by chemical ischemia, hypoglycemia, or oxidative stress. Free Radic Biol Med 1999;26:1405-1417.

19 Kernt M, Arend N, Buerger A, Mann T, Haritoglou C, Ulbig MW, Kampik A, Hirneiss C: Idebenone prevents human optic nerve head astrocytes from oxidative stress, apoptosis, and senescence by stabilizing $\mathrm{BAX} / \mathrm{Bcl}-2$ ratio. J Glaucoma 2013;22:404-412.

20 Ali SA, Aly HF, Faddah LM, Zaidi ZF: Dietary supplementation of some antioxidants against hypoxia. World J Gastroenterol 2012; 18:6379-6386.

21 Abdel Baky NA, Zaidi ZF, Fatani AJ, SayedAhmed MM, Yaqub H: Nitric oxide pros and cons: the role of L-arginine, a nitric oxide precursor, and idebenone, a coenzyme-Q analogue in ameliorating cerebral hypoxia in rat. Brain Res Bull 2010;83:49-56.

22 Shivaram KN, Winklhofer-Roob BM, Straka MS, Devereaux MW, Everson G, Mierau GW, Sokol RJ: The effect of idebenone, a coenzyme $\mathrm{Q}$ analogue, on hydrophobic bile acid toxicity to isolated rat hepatocytes and hepatic mitochondria. Free Radic Biol Med 1998;25:480492.

23 Mosmann T: Rapid colorimetric assay for cellular growth and survival: application to proliferation and cytotoxicity assays. J Immunol Methods 1983;65:55-63.

24 Kernt M, Neubauer AS, Liegl R, Eibl KH, Alge CS, Lackerbauer CA, Ulbig MW, Kampik A: Cytoprotective effects of a blue light-filtering intraocular lens on human retinal pigment epithelium by reducing phototoxic effects on vascular endothelial growth factor-alpha, Bax, and Bcl-2 expression. J Cataract Refract Surg 2009;35:354-362.

25 Dimri GP, Lee X, Basile G, Acosta M, Scott G, Roskelley C, Medrano EE, Linskens M, Rubelj I, Pereira-Smith O, et al: A biomarker that identifies senescent human cells in culture and in aging skin in vivo. Proc Natl Acad Sci USA 1995;92:9363-9367.

26 Nishikawa T, Edelstein D, Du XL, Yamagishi S, Matsumura T, Kaneda Y, Yorek MA, Beebe D, Oates PJ, Hammes HP, Giardino I, Brownlee M: Normalizing mitochondrial superoxide production blocks three pathways of hyperglycaemic damage. Nature 2000;404:787790.
27 Kernt M, Hirneiss C, Neubauer AS, Ulbig MW, Kampik A: Coenzyme Q10 prevents human lens epithelial cells from light-induced apoptotic cell death by reducing oxidative stress and stabilizing $\mathrm{BAX} / \mathrm{Bcl}-2$ ratio. Acta Ophthalmol 2010;88:e78-e86.

28 Kernt M, Liegl RG, Rueping J, Neubauer AS, Haritoglou C, Lackerbauer CA, Eibl KH, Ulbig MW, Kampik A: Sorafenib protects human optic nerve head astrocytes from lightinduced overexpression of vascular endothelial growth factor, platelet-derived growth factor, and placenta growth factor. Growth Factors 2010;28:211-220.

29 Levine AJ: p53, the cellular gatekeeper for growth and division. Cell 1997;88:323-331.

30 McKinnon SJ, Lehman DM, Kerrigan-Baumrind LA, Merges CA, Pease ME, Kerrigan DF, Ransom NL, Tahzib NG, Reitsamer HA, Levkovitch-Verbin H, Quigley HA, Zack DJ: Caspase activation and amyloid precursor protein cleavage in rat ocular hypertension. Invest Ophthalmol Vis Sci 2002;43:10771087.

31 Hinton DR, He S, Lopez PF: Apoptosis in surgically excised choroidal neovascular membranes in age-related macular degeneration. Arch Ophthalmol 1998;116:203-209.

32 Shan H, Ji D, Barnard AR, Lipinski DM, You Q, Lee EJ, Kamalden TA, Sun X, MacLaren RE: AAV-mediated gene transfer of human $\mathrm{X}$-linked inhibitor of apoptosis protects against oxidative cell death in human RPE cells. Invest Ophthalmol Vis Sci 2011;52: 9591-9597.

-33 Xu GZ, Li WW, Tso MO: Apoptosis in human retinal degenerations. Trans Am Ophthalmol Soc 1996;94:411-430, discussion 430-431.

34 Dunaief JL, Dentchev T, Ying GS, Milam AH: The role of apoptosis in age-related macular degeneration. Arch Ophthalmol 2002;120: 1435-1442.

35 Faghiri Z, Bazan NG: PI3K/Akt and mTOR/ p70S6K pathways mediate neuroprotectin D1-induced retinal pigment epithelial cell survival during oxidative stress-induced apoptosis. Exp Eye Res 2010;90:718-725.

36 Cao X, Liu M, Tuo J, Shen D, Chan CC: The effects of quercetin in cultured human RPE cells under oxidative stress and in $\mathrm{Ccl} 2$ / Cx3cr1 double deficient mice. Exp Eye Res 2010;91:15-25

37 Savory J, Rao JK, Huang Y, Letada PR, Herman MM: Age-related hippocampal changes in Bcl-2:Bax ratio, oxidative stress, redox-active iron and apoptosis associated with aluminum-induced neurodegeneration: increased susceptibility with aging. Neurotoxicology 1999;20:805-817.

38 Naderi J, Hung M, Pandey S: Oxidative stressinduced apoptosis in dividing fibroblasts involves activation of p38 MAP kinase and over-expression of Bax: resistance of quiescent cells to oxidative stress. Apoptosis 2003; $8: 91-100$ 
39 Chen J, Chu Y, Cao J, Yang Z, Guo X, Wang $\mathrm{Z}$ : T-2 toxin induces apoptosis, and selenium partly blocks, T-2 toxin induced apoptosis in chondrocytes through modulation of the Bax/ Bcl-2 ratio. Food Chem Toxicol 2006;44:567573.

40 Borner C: The Bcl-2 protein family: sensors and checkpoints for life-or-death decisions. Mol Immunol 2003;39:615-647.

41 Lee JE, Kang JS, Shin IC, Lee SJ, Hyun DH, Lee KS, Koh HC: Fluazinam-induced apoptosis of SH-SY5Y cells is mediated by p53 and Bcl-2 family proteins. Neurotoxicology 2011; 32:702-710

42 Huang XR, Qi MX, Wang ZY, Chen Y: Inhibition effects of compound leech eye drops on apoptosis of lens epithelial cells and expressions of Bcl-2 and Bax genes in rats (in Chinese). Zhong Xi Yi Jie He Xue Bao 2007;5: 681-685.

43 Singh M, Piekorz RP: Senescence-associated lysosomal $\alpha$-L-fucosidase (SA- $\alpha$-Fuc): a sensitive and more robust biomarker for cellular senescence beyond SA- $\beta-$ Gal. Cell Cycle 2013;12:1996.

-44 Ravelojaona V, Robert AM, Robert L: Expression of senescence-associated $\beta$-galactosidase (SA- $\beta-$ Gal) by human skin fibroblasts, effect of advanced glycation end-products and fucose or rhamnose-rich polysaccharides. Arch Gerontol Geriatr 2009;48:151-154.
45 Sin HP, Liu DT, Lam DS: Lifestyle modification, nutritional and vitamins supplements for age-related macular degeneration. Acta Ophthalmol 2013;91:6-11.

46 Mordente A, Martorana GE, Minotti G, Giardina B: Antioxidant properties of 2,3-dimethoxy-5-methyl-6-(10-hydroxydecyl)-1,4benzoquinone (idebenone). Chem Res Toxicol 1998;11:54-63.

47 Ojano-Dirain CP, Antonelli PJ: Prevention of gentamicin-induced apoptosis with the mitochondria-targeted antioxidant mitoquinone. Laryngoscope 2012;122:2543-2548.

48 Sergi B, Fetoni AR, Paludetti G, Ferraresi A, Navarra P, Mordente A, Troiani D: Protective properties of idebenone in noise-induced hearing loss in the guinea pig. Neuroreport 2006; 17:857-861

49 Deigner HP, Haberkorn U, Kinscherf R: Apoptosis modulators in the therapy of neurodegenerative diseases. Expert Opin Investig Drugs 2000;9:747-764.

50 Yamazaki N, Take Y, Nagaoka A, Nagawa Y: Beneficial effect of idebenone (CV-2619) on cerebral ischemia-induced amnesia in rats. Jpn J Pharmacol 1984;36:349-356.
51 Al-Rasheed NM, Faddah LM, Mohamed AM, Abdel Baky NA, Mohammad RA: Potential impact of quercetin and idebenone against immuno-inflammatory and oxidative renal damage induced in rats by titanium dioxide nanoparticles toxicity. J Oleo Sci 2013;62: 961-971.

52 Heitz FD, Erb M, Anklin C, Robay D, Pernet $\mathrm{V}$, Gueven N: Idebenone protects against retinal damage and loss of vision in a mouse model of Leber's hereditary optic neuropathy. PLoS One 2012;7:e45182.

53 Klopstock T, Metz G, Yu-Wai-Man P, Buchner B, Gallenmuller C, Bailie M, Nwali N, Griffiths PG, von Livonius B, Reznicek L, Rouleau J, Coppard N, Meier T, Chinnery PF: Persistence of the treatment effect of idebenone in Leber's hereditary optic neuropathy. Brain 2013;136(Pt 2):e230.

54 Buyse GM, Van der Mieren G, Erb M, D’Hooge J, Herijgers P, Verbeken E, Jara A, Van Den Bergh A, Mertens L, Courdier-Fruh I, Barzaghi P, Meier T: Long-term blinded placebo-controlled study of SNT-MC17/idebenone in the dystrophin deficient $\mathrm{mdx}$ mouse: cardiac protection and improved exercise performance. Eur Heart J 2009;30:116124 